\section{De første nevrologene i Norge}

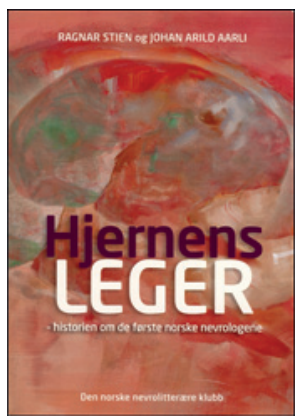

Ragnar Stien, Johan Arild Aarli Hjernens leger

Historien om de første norske nevrologene. 267 s, ill. Oslo: Den norske nevrolitterære

klubb, 2012. Pris NOK 250

ISBN 978-82-996059-2-2

To av norsk nevrologis «grand old men», Ragnar Stien (f. 1938) og Johan Arild Aarli (f. 1936), har skrevet bok om norske nevrologer og en del andre hjerneforskere frem til ca. 1980. Boken består av 13 kapitler, de første sju er inndelt kronologisk, det siste er en samling av nyttige oversikter, inkludert en liste over milepæler i norsk nevrobiologi.

Forfatterne kaller årene 1921-54 for «Monrad-Krohn-perioden» etter fagets professor, Georg Herman Monrad-Krohn (1884-1964). Det er interessant å lese deres beskrivelser. De skriver rett ut om hans rykte som «despotisk sjef», uendelig selvsentrert, selvhevdende, dominerende og diktatorisk. Også beskrivelsene av andre personer er friske og ærlige. Om de neste professorene i faget, Arne Galtung Frøvig (1907-92) i Bergen og Sigvald Refsum (1907-91) i Oslo, står det at de var «ytterst formelle og korrekte, de unngikk konflikter og hadde betydelige forventninger om anerkjennelse av professors absolutte autoritet» (s. 148).

Kanskje det aller mest interessante kapitlet er De som ble stående på siden. Det er en omtale av personer som av ulike grunner (en av grunnene var Monrad-Krohn) utviklet sine interesser utenom den opptrukne linje. Den eneste nålevende av disse er Alette (Letten) Fegersten Saugstad (f. 1925), som antakelig var den første kvinnelige spesialisten i klinisk nevrofysiologi i Norge. Hun omtales som «en nesten mytisk og lite kjent figur i norsk nevro-biologi» med en «formidabel publikasjonsliste». Hun har søkt 11 akademiske stillinger, vært klart best kvalifisert for dem alle, men ikke fått noen (s. 187). Her etterlates leseren med ubesvarte spørsmål. Det samme gjelder beskrivelsen av Ardis Storm-Mathisen (1912-2000), som leverte en avhandling til bedømmelse i 1961, men den ble ikke funnet «verdig» til å forsvares for doktorgraden. I motsetning til omtalen av andre avviste avhandlinger (Arne Torkildsen og Audun Schjøtt) får vi ikke vite mer om dette, og man må bare undres om det er riktig som forfatterne antyder - at hun ble avvist fordi miljøet ikke riktig visste hvordan man skulle takle en kvinnelig konkurrent til de akademiske toppstillingene i faget (s. 164).

Kildehenvisningene skulle jeg ønsket var bedre. Litteraturreferansene er relativt få, og det er mange steder vanskelig å finne ut hvor opplysningene stammer fra. Det samme gjelder illustrasjonene. Forfatterne må ha lagt ned et stort arbeid i å skaffe disse til veie, men hvor er de hentet fra? I forordet takkes ektefellene for å ha holdt ut med dem som «arkivrotter», men hvilke arkiver som er undersøkt, fremgår ikke.

Boken er velskrevet og rikt illustrert. Forfatterne øser av store kunnskaper og fremviser en imponerende oversikt. Nevrologer angis som den viktigste målgruppen, men boken vil være av stor interesse for langt flere. Dette er ikke en tekst for de spesielt interesserte. Den vil glede alle med interesse for medisinsk historie.

\section{Den spanske borgerkrig og bøkene}

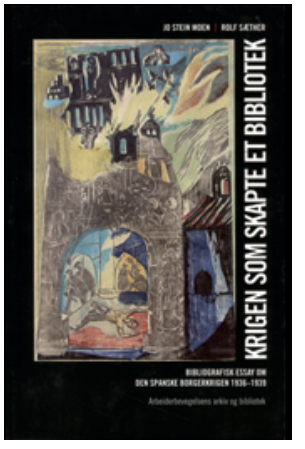

\section{Jo Stein Moen, Rolf Sæther}

Krigen som skapte et bibliotek

Bibliografiske essay om den spanske borgerkrigen 1936-1939. 205 s, ill. Oslo: Arbeiderbevegelsens arkiv og bibliotek, 2011. Pris NOK 120

ISBN 978-82-90759-23-5

Den spanske borgerkrigen varte i mindre enn tre år, fra sommeren 1936 til våren 1939. Det kan i ettertid virke merkelig at en borgerkrig i Europas ytterkant kunne få så stor oppmerksomhet, ikke bare i samtid, men også i ettertid. Forklaringen ligger i oppfatningen av krigen som en opptakt til den annen verdenskrig. Den tyske bombingen av Guernica er gjennom Picassos bilde blitt selve symbolet på krigens grusomhet. Arnulf Øverlands (1889-1968) dikt med samme tittel fra 1937 er stadig verdt å lese. Alle var der, blant dem Ernest Hemingway (1899-1961), George Orwell (1903-50), André Malraux (1901-76), Pablo Neruda (1904-73) og Nordahl Grieg (1902-43). Av det ble det selvfølgelig litteratur. Den mest kjente romanen er Hemingways For whom the bell tolls (1940), som kom på norsk i 1946: Klokkene ringer for deg.

Men det ble mer enn skjønnlitteratur. Seierherrene skrev sin historie i 35 bind, men også det verket drukner i de ca. 30000 bøkene og skriftene som er kommet hittil. Og krigen fortsetter å fengsle. Jan Jakob Tønseths (f. 1947) trilogi om spaniaveteranen og ekskommunisten Hilmar Iversen kom 1992-2002, biografien om krigsjournalisten Lise Lindbæk (1905-61) i 2002 og den britiske historikeren Anthony Beevors (f. 1946) bok Kampen om Spania i 2006.

I 2009 utga Jo Stein Moen og Rolf Sæther Norge og den spanske borgerkrigen 1936-1939, der også norske legers innsats på det norsk-svenske sykehuset i Alcoy, ca. 10 mil sør for Valencia, ble beskrevet (1). Nå har Moen og Sæther skrevet en ny bok, og den handler om nettopp det tittelen sier, bibliografiske essays og leserhenvisninger for de som ønsker å lese mer om borgerkrigen. Det er henvisning til 1000 tekster, og boken er gjennomillustrert av fotografiene til lege Gunnar Finsen (1907-86). Han arbeidet ved det norsk-svenske sykehuset i 1937, og bildene ble funnet på et loft i Oslo da forfatterne arbeidet med boken om selve krigen. Finsen skrev flere år senere at «Av de tre kriger jeg har vært med på å tape, har den spanske borgerkrigen gjort det dypeste inntrykk på meg». De to andre var den finsk-russiske vinterkrigen 1939-40 og tyskernes angrep på Norge våren 1940. Da var Finsen frivillig på Hegra festning.

Men boken er mer enn en bibliografi for spesielt interesserte. Den gir samtidig en innføring i en av det 20. århundres skjellsettende begivenheter. Finsens bilder, nå digitalisert av Arbeiderbevegelsens arkiv og bibliotek, gjør den spesielt interessant for Tidsskriftets lesere.

\section{Per E. Børdahl}

Kvinneklinikken

Haukeland universitetssykehus

\section{Litteratur}

1. van der Hagen CB. Nordmenn i den spanske borgerkrigen. Anmeldelse av Moen JS, Sæther R. Tusen dager. Tidsskr Nor Legeforen 2009; 129: 2675. 